\title{
New Taxa of Signal Flies (Diptera: Platystomatidae) of New Caledonia
}

\author{
David K. McAlpine \\ Australian Museum, 6 College Street, Sydney NSW 2010, Australia
}

\begin{abstract}
Possible explanations are sought for the distribution patterns of platystomatid genera in Pacific Oceania, with special reference to those of New Caledonia. A key to the eleven known genera of New Caledonia (including the Loyalty Islands) is given. Five of these genera are endemic to this province of the Australasian Region. A key to the known Australasian species of Naupoda is given. Dayomyia molens n.gen. and n.sp., Eumeka koghii n.sp., Pogonortalis monteithi n.sp., Sors wrightae n.gen. and n.sp., and Naupoda (Gonga) burwelli n.sp. are described from New Caledonia (Grande Terre). Abrasion of part of the antenna in $D$. molens is apparently due to some unexplained behavioural trait.
\end{abstract}

McAlPIne, DAvid K., 2007. New taxa of signal flies (Diptera: Platystomatidae) of New Caledonia. Records of the Australian Museum 59(1): 65-77.

\section{Introduction}

New Caledonia has a rich fauna of Platystomatidae for such a small and isolated group of islands, and has a high rate of endemicity. Ongoing incomplete studies show the presence of at least eleven genera and 47 species. Lamprogaster Macquart and Signa McAlpine are the genera with the largest representation, but only one New Caledonian species of each is yet described. This paper, dealing with five small, apparently uncommon genera, foreshadows further work on this fauna. The number of available specimens of each new species is small, and recent focused field work by colleagues (2006) has failed to bring to light any more material of these. However, the novel status of the species is not in doubt, and I believe that the two new genera are well founded.

\section{Methods}

Morphological terms are those used by me previously (McAlpine 1973). Paired bristles and other structures are described in the singular, except where the context makes this inappropriate. The antenna is treated as a six-segmented appendage and segments are numbered from the base. Segments 4 to 6 constitute the arista. Cell- 4 index is defined as the ratio of the length of the antepenultimate section of vein 4 to the full length of the discal cell along vein 4 . Width of mesoscutum is measured across the notopleural calli.

The following collectors names are abbreviated to the initials: C.J. Burwell, N.L. Krauss, G.B. Monteith, J. Wright, S.G. Wright, C. Yoshimoto. 